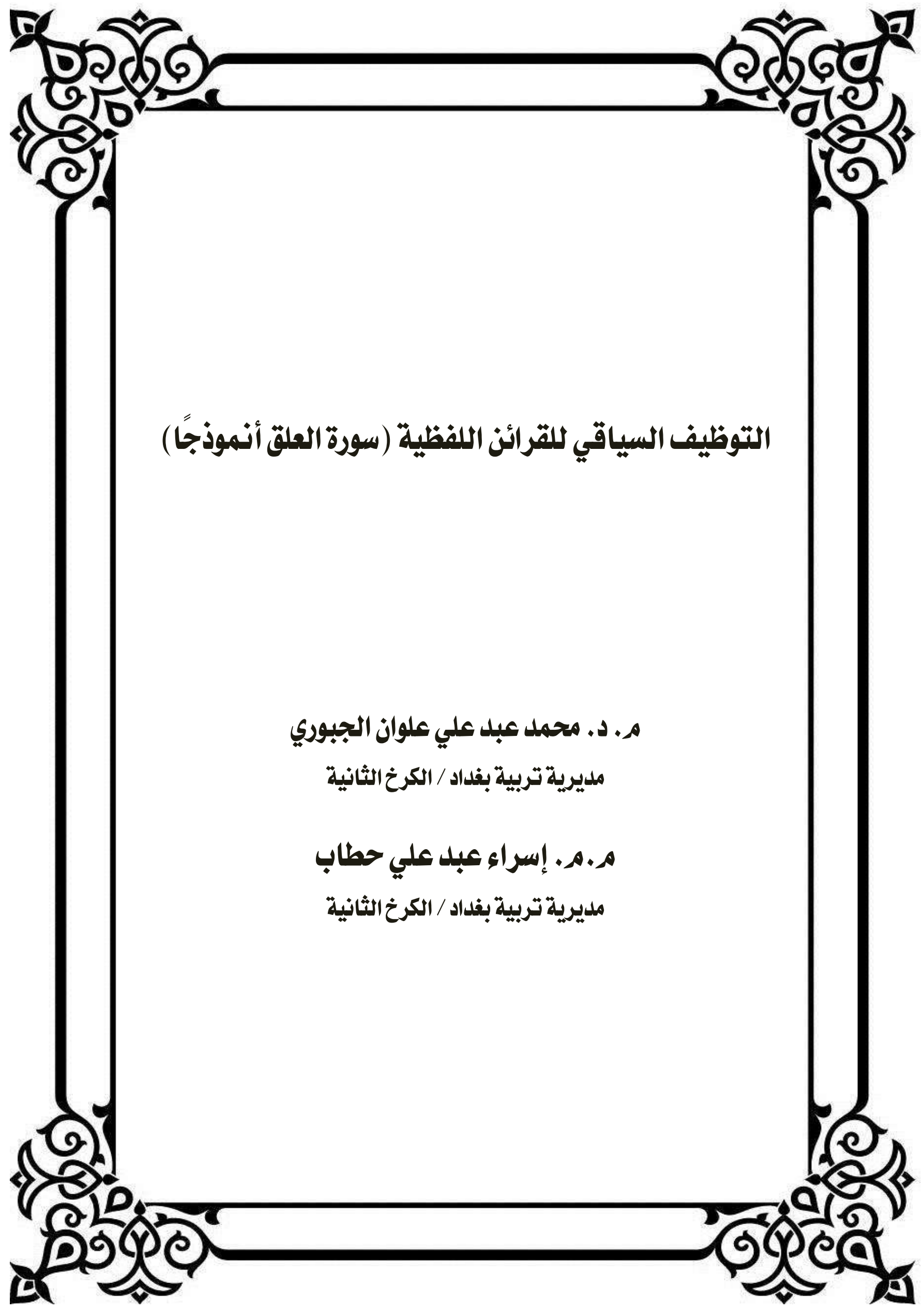





\section{التوظيف السياقي للقرائن اللفظية (سورة العلق أنموذجًا)}

م. د. محمد عبد علي علوان الجبوري

م.م. إسراء عبد علي حطاب

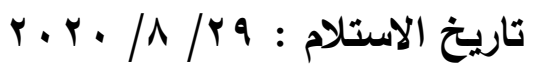

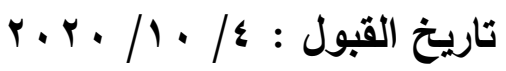

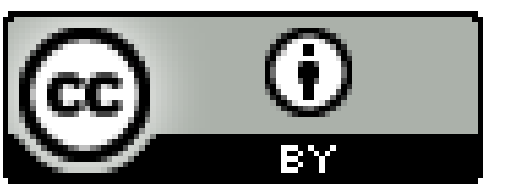

This work is licensed under a Creative Commons Attribution 4.0 International License

الملخص

عني البحث بتوظيف بعض القرائن اللفظية ( الصونية ، والصرفية ، والنحوية ) للوصول إلى

قصدية الخطاب القرآني ، ومن هنا تتواشج هذه النظم في تحديد ماهية السياق اللغوي وهذا ما تتمركز عليه فكرة بحثنا لتكثف آلية العلاقة الجدلية الناجمة من تفاعل هذه النظم.

الكلمات المفتاحية: المعنى الوظيفي ، السياق ، القرائن الصرفية ، تفاعل النظم

\section{The Contextual Employment of Verbal Clues (Surat Al-Alaq as a Model)}

Dr. Muhammed Abed Ali Alwan Al-Juboori

Baghdad Education Directorate / Al-Karkh ( Second)

muhammed@gmail.com

Asst. Lect. Israa Abed Ali Hattab

Baghdad Education Directorate / Al-Karkh ( Second) israa@gmail.com

\section{Abstract}

The research is concerned with employing the verbal clues (phonemic, morphological, and grammatical) to reach the intentionality of the Qur'anic discourse, and consequently, these systems collide in determining what the 
linguistic context is, and this is what the idea of the current research is centered on to reveal the mechanism of the dialectical relationship resulting from the interaction of these systems.

Key words : Functional meaning, context, morphological clues, interactional system

المقدمة

لما كان القرآن محور عقيدة الأمة، ومصدر حضارتها ومستودع تشريعها كان حقًا على

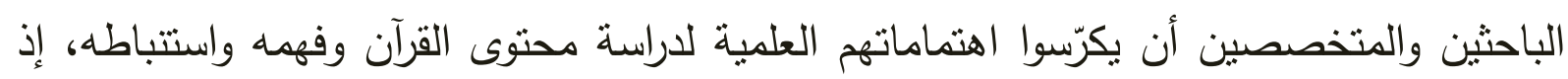

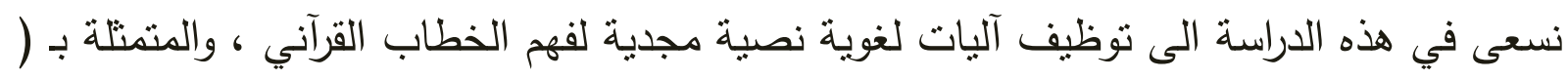
القرائن اللفظية ) ، ومعرفة مدى الإفادة من هذه القرائن في الدرس اللغوي ؛ لكونها مفتاحاً لفهم

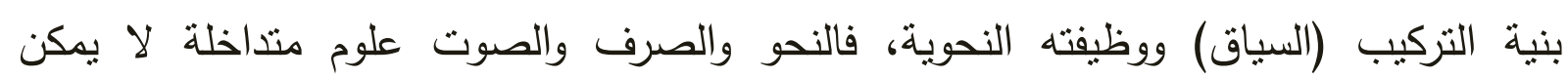

الأول: المستوى الصوتي: ويعنى بمخارج الحروف وأصواتها ومقاطعها والظواهر التي ترافقها فالفعل (ضَرَبَ) يتألف من ثناثة مقاطع صوتية:

بَ $\tau^{+}$

$$
\text { تجزئتها، فأحدها مكمل للأخر . إذ إن التركيب اللغوي يتألف من أربعة مستويات: }
$$


الثالث: المستوى المعجمي: هو معنى الكلمة المفردة الذي ينشأ بعد نوليف في المستوى الصرفي فالفعل (ضرب) يدل على حدث الضرب الذي وقع في زمن ماضٍ. الرابع: المستوى النحوي: ويمثل العلاقات التركيية بين المفردات عند تأليف الجملة مثل علاقة المسند بالمسند إليه، والتبعية ... الخ. وهذا التواشج بين المستويات الأربعة يتمخض عنه المعنى الدلالي. وعلى الرغم من وجود هذه المستويات، إلا أن النظرة الى اللغة العربية بوصفها تمثل نراكيب لغوية انسمت بطريقتين: إحداهما تتظر من الكل الى الجزء، والثانية من الجزء الى الكل. فلو تمعنا في كلام ابن ماللك:

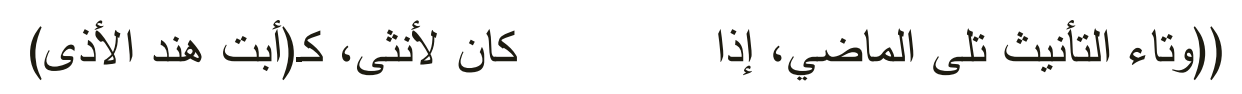

إذا اسند الفعل الماضي الى مؤنث لحقته تاء ساكنة تدل على كون الفاعل مؤنثًا، ولا فرق في ذلك

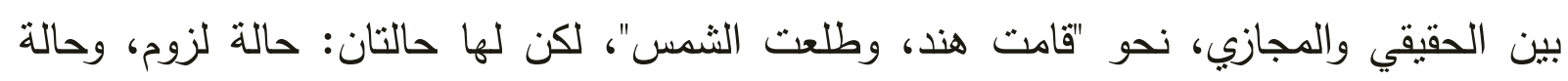

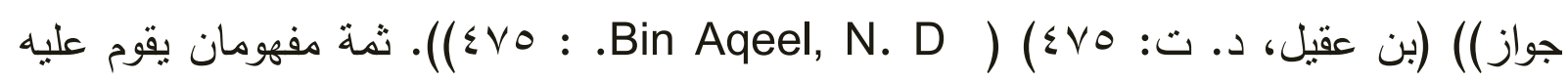
هذا الكلام هما: المفهوم الصرفي، والمفهوم النحوي، فنلحظ أن التأنيث يندرج تحت مفهوم (المعنى)، أما وجود التاء على إطلاقها فتدل على (المبنى)، والتاء في(أبت) تثير الى العلامة

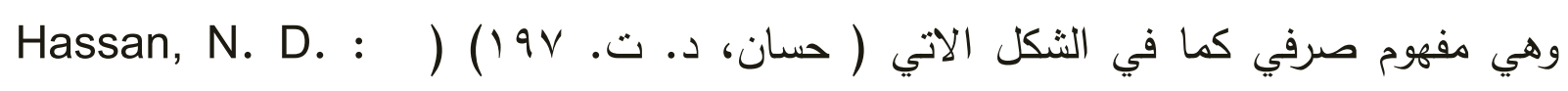
197)) :

العلامة

المبنى المعنى التاء في (أبت) التاء على إطلاقها التأنيث ومن ثم ترى العلاقة التركيبية في مطابقة التأنيث بين الفعل والفاعل من ناحية ((المعنى)) والتاء

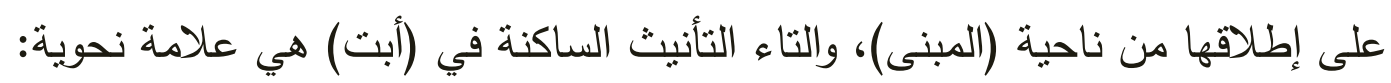
نخلص الى أن التأنيث هو (معنى) وان المؤنث هو (مبنى) له، قد يعبر عنه بمفردة مختومة بتاء التأنيث أو مختومة بألف مقصورة أو مددودة، أما الأنثى فلا علاقة لها بذلك كله، لهانه 
لان الأنوثة ضد الذكورة هذا في الطبيعة، أما التأنيث فهو ضد التذكير في اللغة. ( حسان، Hassan, 2000:8) ) (^:ץ...

لذا نرى أن اغلب العلمـاء خـالطوا بين النحو والصـرف وهذا مـا نلحظه عند القدماء، فيحاولون إيجاد الحلول لإشكاليات بنية الكلمة( الصرف) والمعنى الوظيفي (النحو) بصورة مستقلة لكل منهما ((ومن هنا جاءت منون القواعد مشتملة على مزيج من هذا وذاك يصعب معه إعطاء

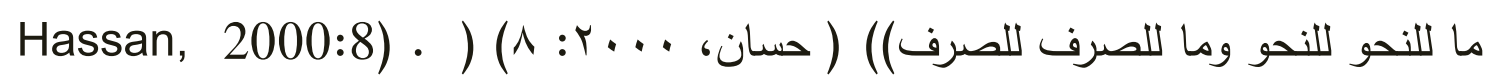
وعلى هذا الأساس يتضح لنا أن الصرف والنحو والصوت أنظمة ممتزجة داخل التركيب في الجملة لا يمكن لأحدهما الاستغناء عن الأخر.

وإذا عدنا الى موضـوع بحنتـا وهـو ((التوظيـف السـياقي للقـرائن اللفظيـة)) نجد أن هذا

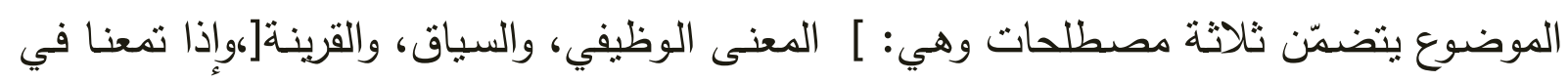

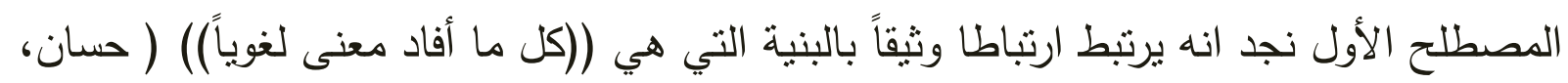

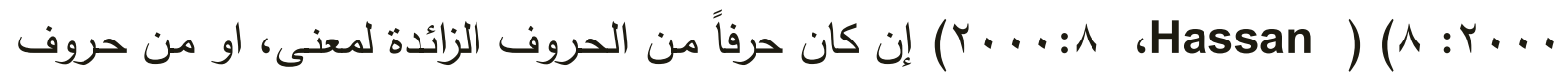

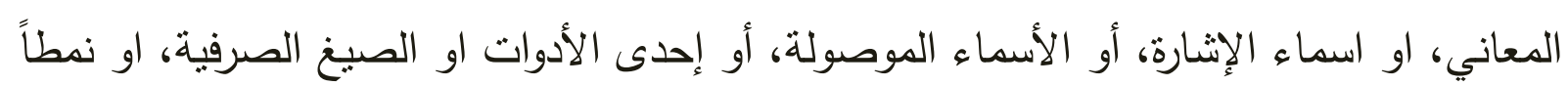

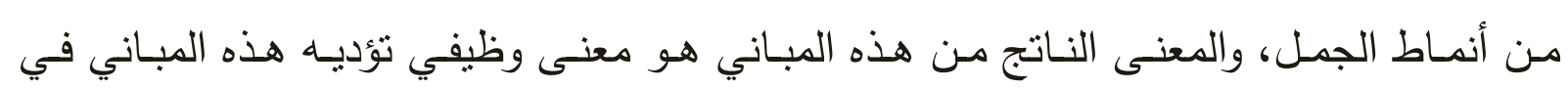

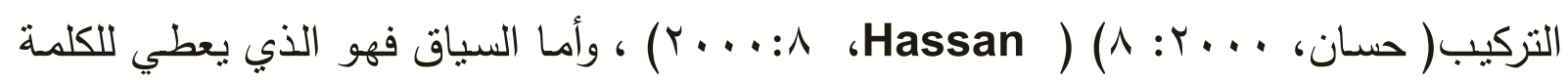
دلالة أخرى غير دلالتها المعجية الأساسية في سياق معين دون سياقات أخرى فاللفظة (( توجد

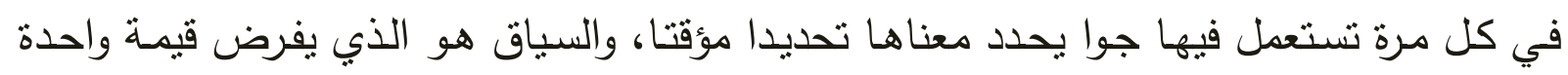

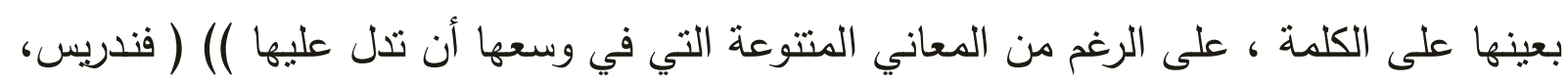

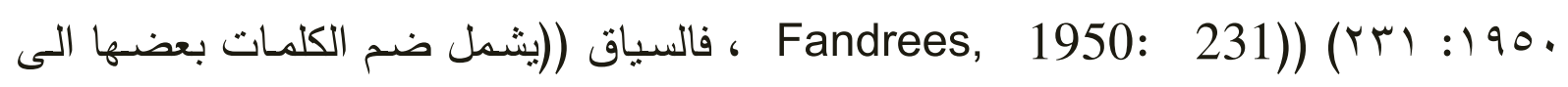
بعض وترابط أجزائها واتصالها أو نتابعها وما توحيه من معنى ، وهي مجتمعة في النص)) (وهبة (لوبة

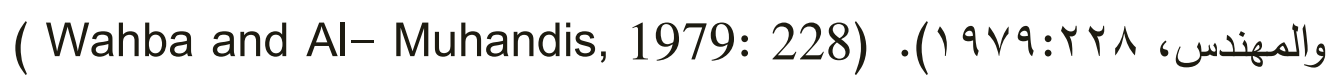

أما القرينة فهي من المصطلحات اللغوية التي بيتندل منها على الوظيفة النحوية سواء كانت قرينة لفظية محددة بأحد أنساق الكلام إذ تشمل: ] العلاقة الإعرابية، والربط، والأداة، والرتبة،

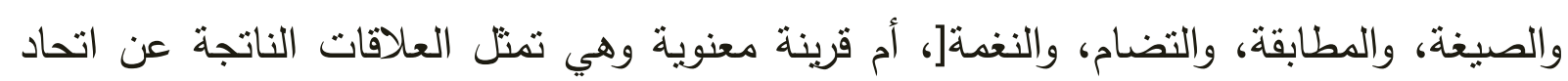


عناصر الكلام داخل التركيب اللغوي من الجملة الواحدة كالعلاقة ] الاسنادية، والمعية، والظرفية،

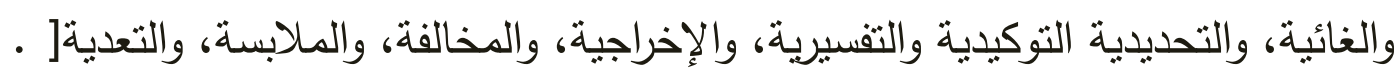
ولابد من الإثارة الى أن هناك قرينة جامعة مانعة تتدرج تحت مصطلح (القرينة المعنوية) لكنها أخص منها وهي قرينة (التخصيص) فهي ((قرينة معنوية كبرى تتفرع عنها قرائن معنوية

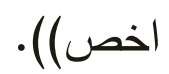

ومن اتحاد القرائن اللفظية والقرائن المعنوية داخل التركيبي اللغوي تتجم ظاهرة مهمة ألا وهي ظاهرة ((تضافر القرائن)) لإيضاح معنى التركيب الواحد ، وهذا ما يمكن ان يندرج تحت قرينة

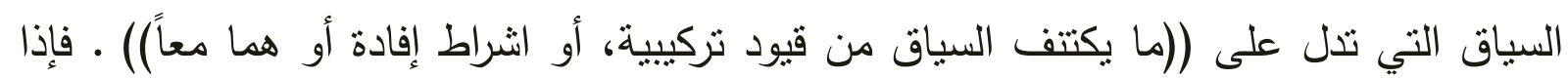

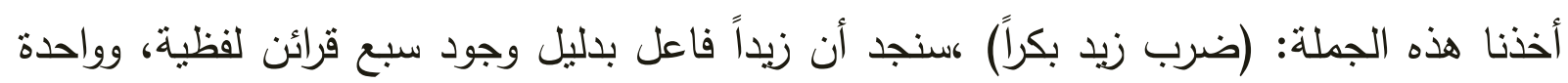

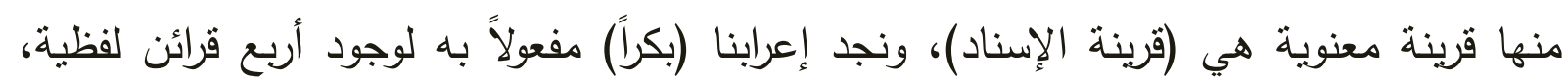
وواحدة معنوية هي (التعدية)، ففي (ضرب زيد) تتجلى القرائن اللفظية الآتية ] العلامة الإعرابية،

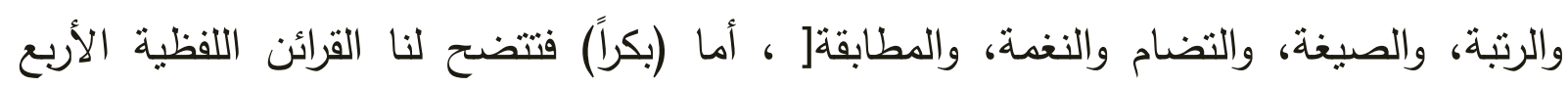

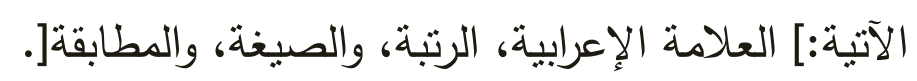

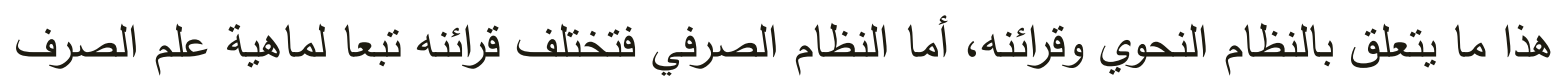

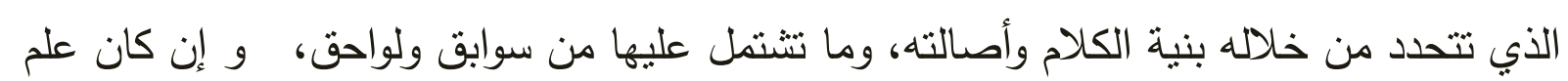

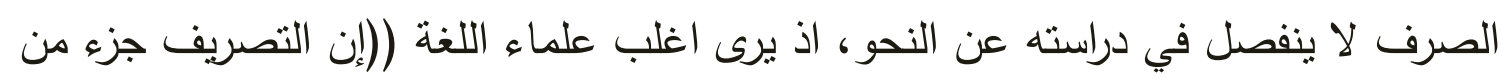

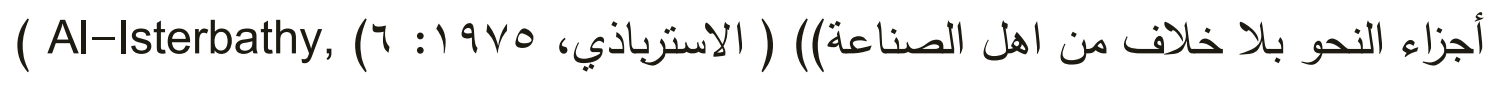
1975: 6) .

يعد تقسيم الدكتور تمام حسان ابرز ما جاء في تحديد القرائن الصرفية وتوضيحها، إذ قسمت

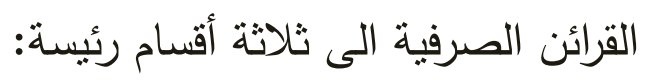
ا مرينة البنية.

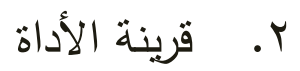




$$
\text { القرائن العلائقية: }
$$

أــ قرينة البنية: يندرج تحت هذا العنوان موضوعات علم الصرف العربي بما يثتمل من تفرعات وتقصيلات تخص بنية الكلمة، إذ تتهيكل قرينة البنية على سبعة مرتكزات اساسية هي (حسان،

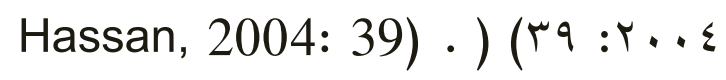

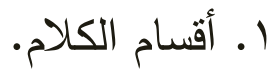

$$
\text { r. r. الجمود والاشتقاق. }
$$

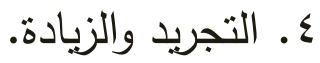

هـ الصيغة الصرفية والميزان الصرفي.

7. اسناد الافعال الى الضمائر .

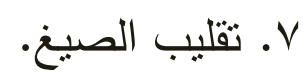

ب_ قرينة الأداة: لا تقل هذه القرينة في أهميتها عما اندرج تحت قرينة البنية، فمنها ما يعد واسطة ترتكز عليها العلاقة الاسنادية بين طرفيها، او بين الجمل وجوابها، ومنها ما يدخل على الكلمات في داخل الجملة فيربط بين عناصرها. هذا ما بتعلق بالأدوات أولات المعاني، وأرجح تقسيم الدكتور تمام حسان للأدوات الداخلة على الجمل بحسب معانيها، إذ وردت كالاتي:

$$
\begin{aligned}
& \text { ـــالأمر } \\
& \text { ـ التوكيد } \\
& \text { • } \\
& \text { بـ الإيجاب } \\
& \text { 1'_النداء } \\
& \text { بـ النفي } \\
& \text { r } \\
& \text { __ الاستفهام }
\end{aligned}
$$




$$
\begin{aligned}
& \text { سا _ التعجب } \\
& \text { ـ ــ الترجي }
\end{aligned}
$$

$$
\text { __ _ الاستغاثة }
$$

$$
\text { _ا _المعية }
$$

r _ حروف يجر الاسم في حيزها

سا _ حروف نزاد في الكلام للتأكيد

$$
\text { ـ التشبيه }
$$$$
\text { 1 } 10
$$$$
\text { ا } 17
$$$$
\text { _ IV }
$$$$
\text { 11 التفسير }
$$

$$
\text { __ الثرط }
$$$$
7
$$

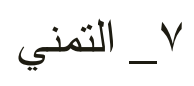

\section{أما حروف المعاني فنتيمل على:}

$$
\text { _ المصدرية }
$$

ب - العطف

بـ الاسنثناء

_ _الاستفتاج

$$
\text { __ الثرط }
$$

7 _ حروف ينصب المضارع في حيزها

_ _ حروف يجزم المضارع في حيزها

^_ الاستدراك

_ _ الاضراب

• ـ الملابسة

ج/ القرائن العلائقية: وهي تشمل ا ـ قرينة التضام.

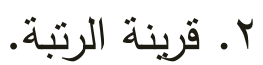

ب. قرينة الربط.

ـ_ قربنة التضام: تتألف الجملة من مفردات تحكمها ضوابط لا عن طريق المصادفة، اذ تقوم على نظامين لا بمكن لاحدها الاستغناء عن الاخر ، هما: 
النظام الأول: المناسبة النحوية: ونعني بها ما تثنمل عليه الجملة من قواعد النحو العربي واصوله

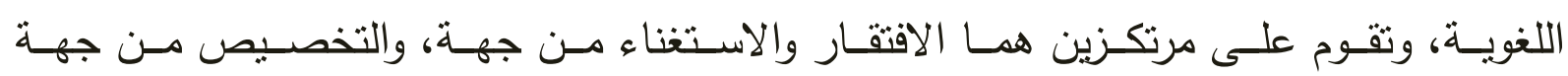
اخرى.ونقصد بالافتقار هو ((ان لفظاً ما لا يستقل بالإفادة ولا يوقف عليه في الكلام غالباً وانما يتطلب في حيزه لفظاً اخر لا غنى له عنه)) ، والاستغناء هو عكس الافتقار كما وصفه النحاة.

اما الاختصاص فهو دخول الحرف على مدخوله بعينه، فعلى سبيل المثال (إنّ) هي حرف مشبه بالفعل معناه يفيد (التوكيد)، يمكن الوصول الى هذا المعنى بسبل اخرى كالتوكيد

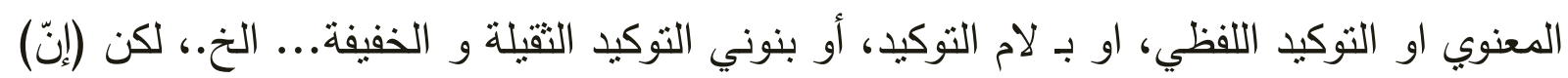

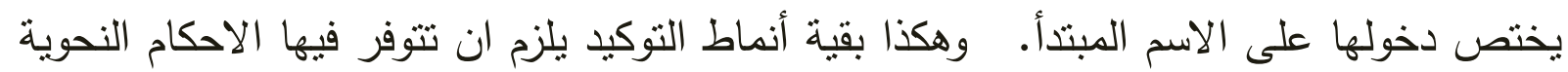

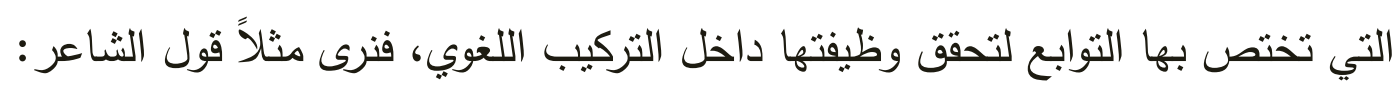

$$
\text { أخالك أخاك إن من لا أخاً له كساع الى الهيجا بغير سلاح }
$$

إن لفظة (أخاك) الثانية جاءت توكيداً لفظياً للأولى وهو ما يحقق لنا غاية التوكيد، وكقوله تعالى

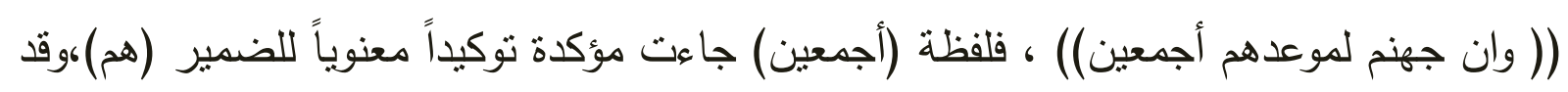

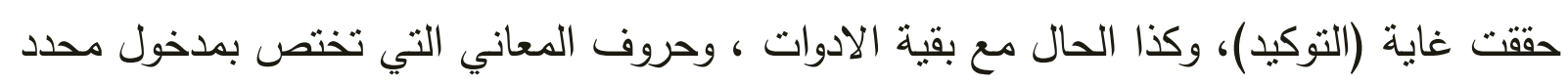
لا يمكن أن تأتي مع سواه.

النظام الثاني: المناسبة المعجية: إذ لا يتحقق لنا مفهوم الجملة بالارتكاز على النظام الأول

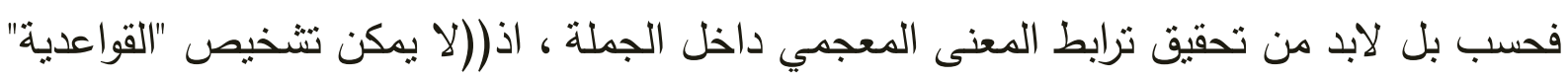

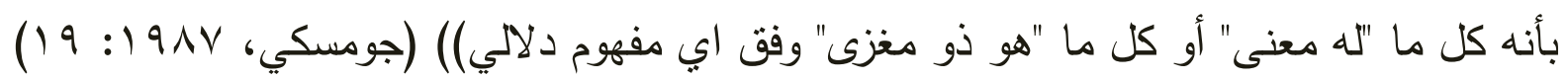

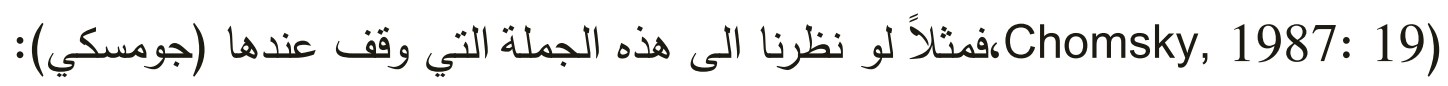

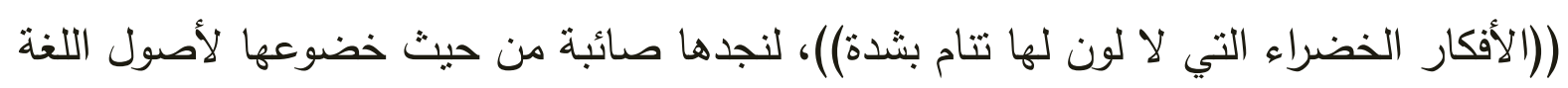

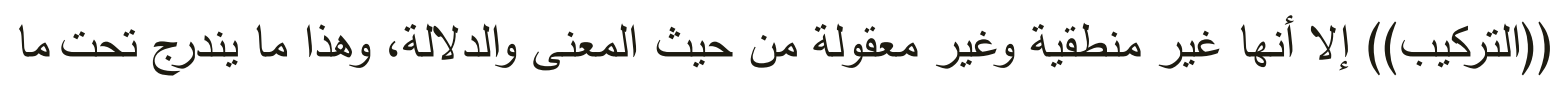
يمكن أن نسميه بالتنافر المعجمي. وبهذا الاقتران والتمازج بين النظامين يتحقق لنا المفهوم العام للجملة تقعيداً ومعنى من خلال قرينة التضام. ؟ _ قرينة الرتبة: تتجلى ضرورة هذه القرينة بذلك التراتب النحوي بين عناصر الجملة فهي اما ان

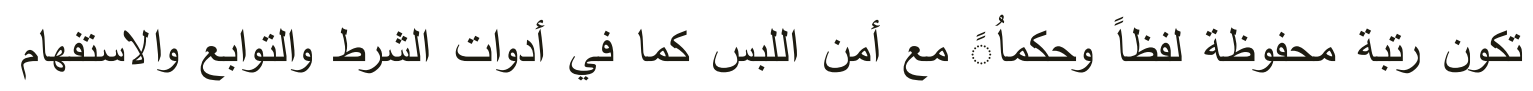


على سبيل المثال لا الحصر، كما في قوله عز وجل: (الم تر كيف فعل ربك بأصحاب الفيل ((،فهزة الاستفهام هي من الحروف التي لها الصدارة في الكلام فلا يمكن ان يسبقها

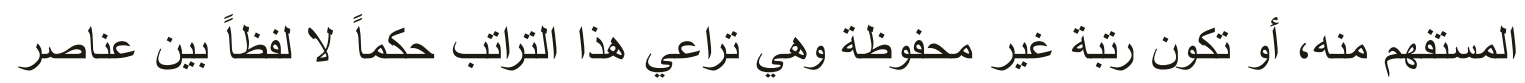

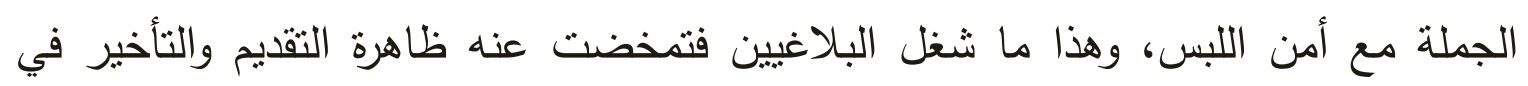

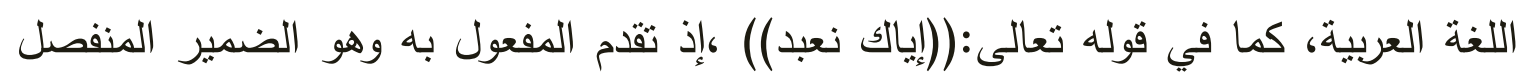

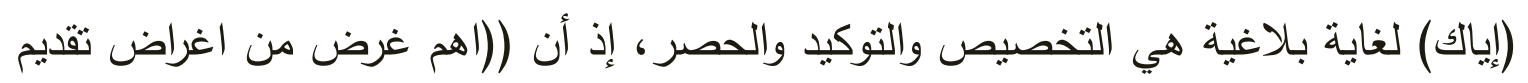
الظرف هو الاختصاص والحصر )).

ץ__ قرينة الربط: ليست هذه القرينة اقل شاناً وأهمية من سابقتيها ] قرينة التضام وقرينة الرتبة[لأنها تتنرك مع القرينتين السابقتين في تحقيق ما بسمى بظاهرة (السبك) داخل

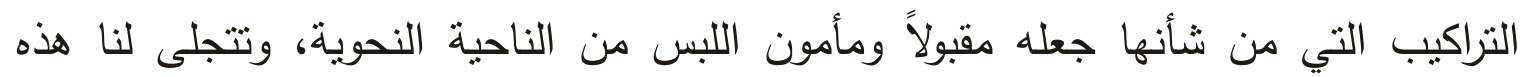
القرينة من سبيلين مختلفين:

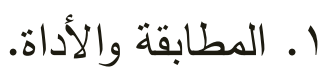

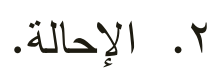
أ_ المطابقة والأداة: تتمحور فكرة المطابقة حول ذلك التماثل في الصيغ الصرفية والضمائر من حيث (العلامة الإعرابية)، و (التعريف والتتكير)، و (التأنيث والتذكير) و (الأفراد والتثنية والجمع) ، ومن حيث (ضمير المتكلم والخطاب والغائب).

اما الأداة: فقد نوهنا إليها آنفاً وأثنرنا الى معانيها ومواقعها في الرتبة المحفوظة، فالأدوات دلالتها

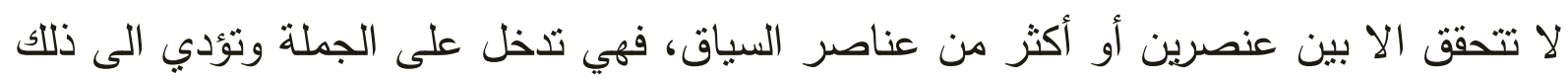

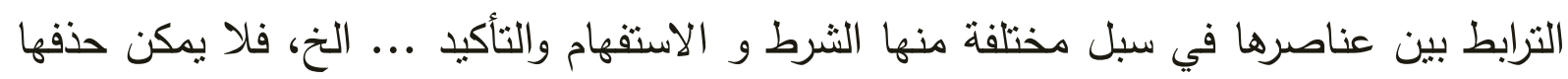

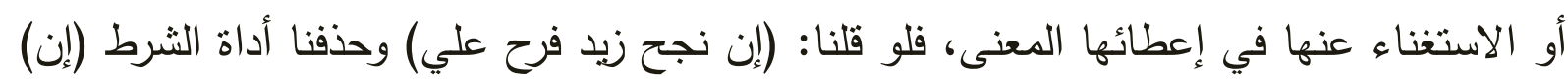

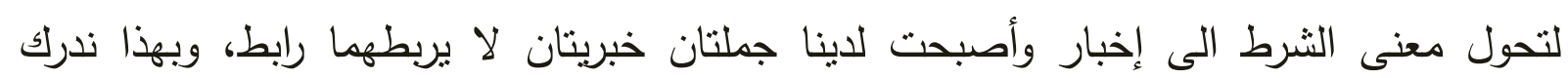
اهمية هذه الادوات الداخلة على الجملة.

ب_ الاحالة: وهذه الظاهرة تمثل جانباً اخر من جوانب قرينة الربط وهي الاتيان والتذكير بعنصر

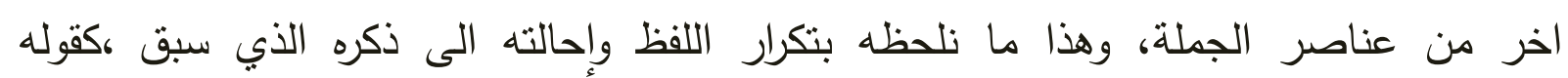
تعالى:((أهدنا الصراط المستقيم، صراط الذين أنعمت عليهم غير المغضوب عليهم ولا الضالين)) 


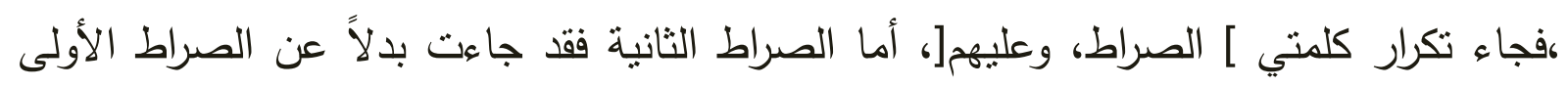

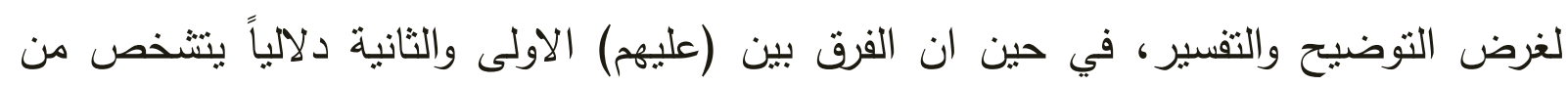

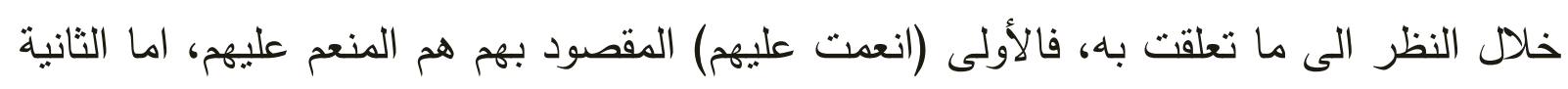
فهم المغضوب عليهم. وتتمخض عن هذه الظاهرة أساليب عدة وردت في القرآن الكريم. ولا تقتصر قرينة الربط على المفردات داخل الجملة او التركيب بل تتعداها الى الربط بين الجمل كعلاقة التفسير والإضراب والاستدراك والسببية على سبيل المثال لا الحصر ، فالسببية كقوله

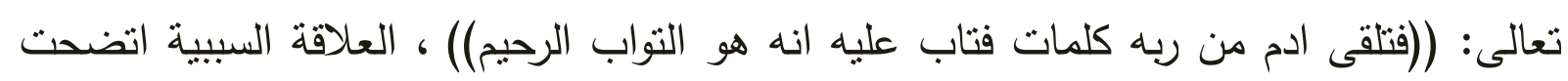

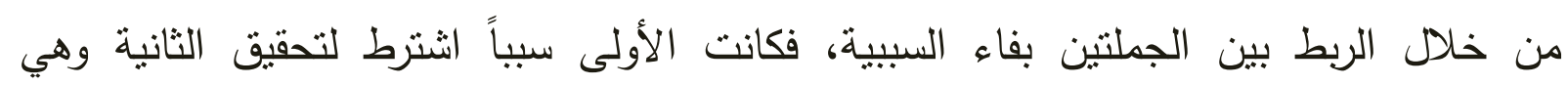

\section{((القرائن اللفظية في سورة العلق وتوظيفها السياقي في التحليل النصي)()}

إن معرفة القرائن في السياق نسهم إسهاما فاعلاً في التحليل النصي، لذا فان تخصيصنا سورة ما جاء ليكثف عن مدى صلاحية هذه القرائن وكيفية توظيفها في التحليل.

\section{مطلع السورة المباركة}

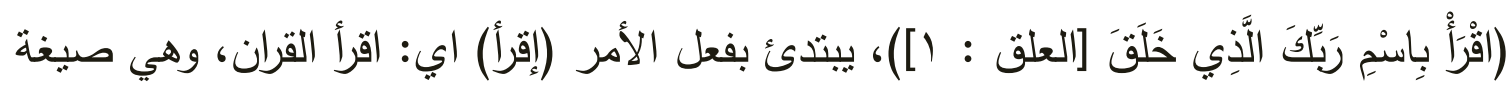

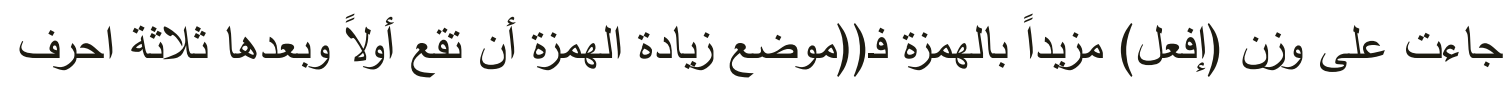

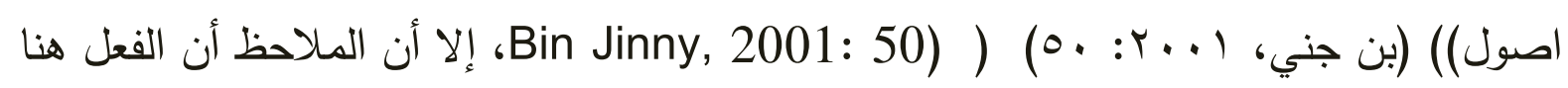
فعل يحتاج الى انجاز ، والدليل على ذلك اجترار قصة نزول الوحي على النى النبي محمد (صلى الله عليه واله وسلم)، وطلب القراءة منه، والفعل الانجازي له وظيفة تداولية قصدية الغاية منها انجاز الفعل، ولو توسعنا قليلاً فان عملية الانجاز لا تستلزم الفعل فقط، وإنما يتوسع مفهوم الفعل (البنية)

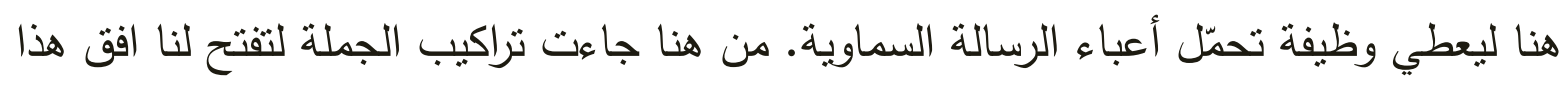

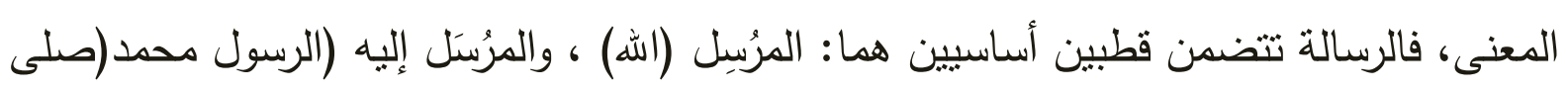

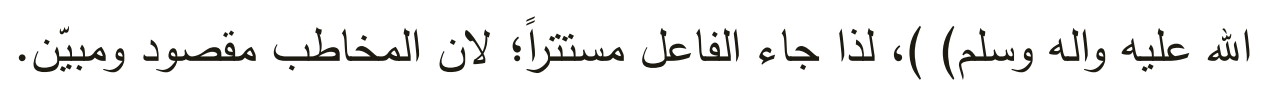
اما (باسم ربك) فقد جاء مقروناً بالباء وهو حرف من حروف المعاني التي لها دلالة واسعة

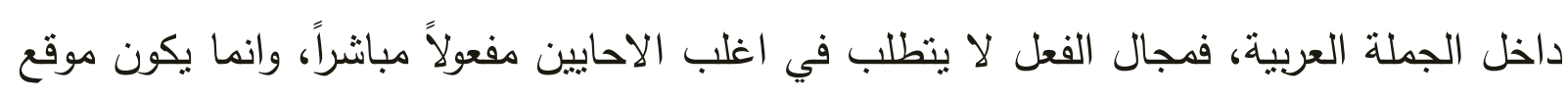


المفعول (المبنى ) مقترناً بوظيفة شكلية تختلف عن المفعول به، وقد جاء في التفسير الكبير ان "باسم ربك" لها وجوه عدة في التأويل منها :

الوجه الاول :

ان الباء زائدة، ويكون معناه (إقرأ اسم ربك)، اي اذكر اسمه، وهذا القول ضعيف لا سباب اولها:

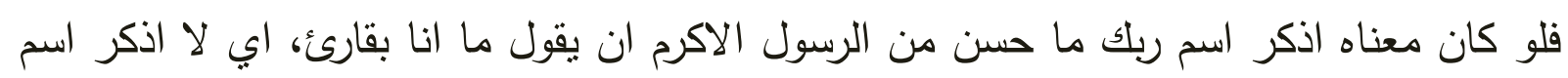

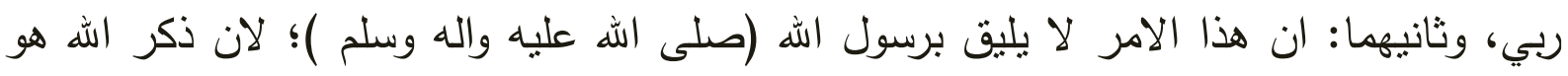

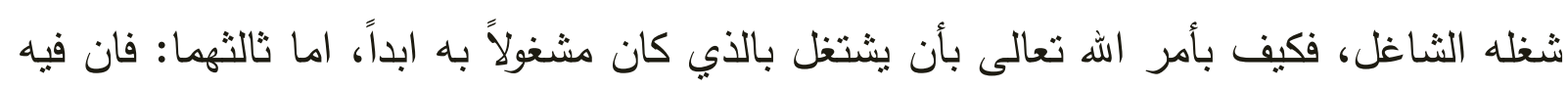
تضييع لحرف الباء وجعلها من دون فائدة.

\section{: الوجه الثناني}

$$
\text { معناه (اقرأ القرآن)، وبهذا يحتمل (باسم ربك) وجوهاً عدة، منها : }
$$

ان يكون محل (باسم ربك) النصب على الحال، والتقدير : (اقرأ القرآن مفتتحاً باسم ربك أي قل بسم الله ثم اقرأ)، وهذا خير دليل على وجوب قراءة البسملة مع كل سورة من سور القرآن

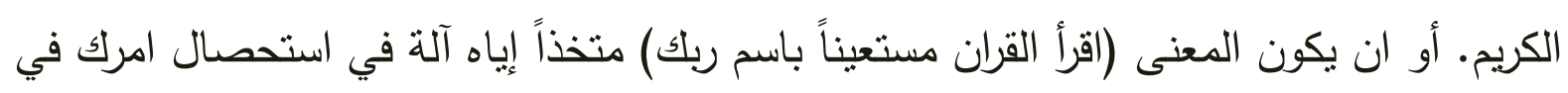

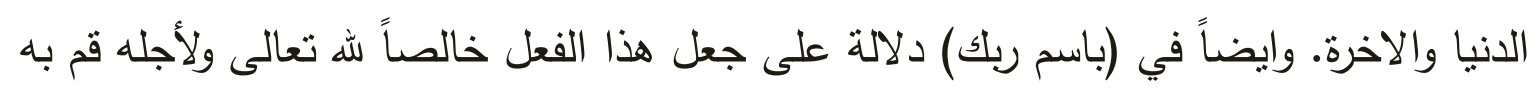

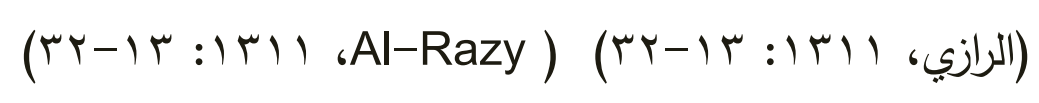

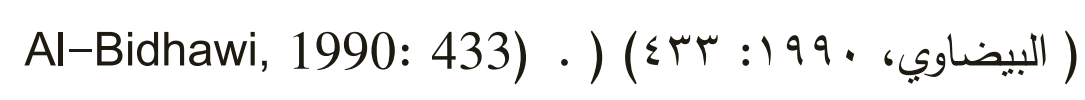

وبهذا فان الوجه الثاني يكون اكثر وضوحاً في تحديد الاسباب والعلل المتعلقة بوجود (الباء)

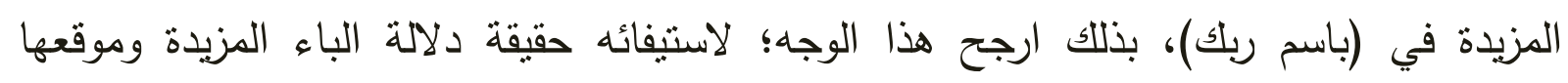
الاعرابي من حيث نصب الجملة على الحالية.

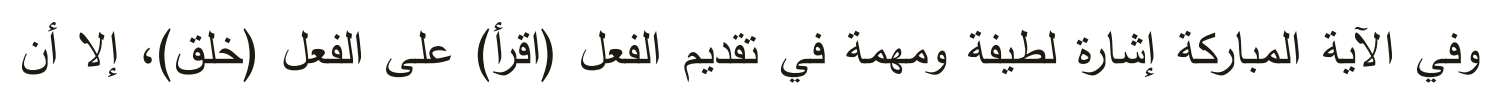

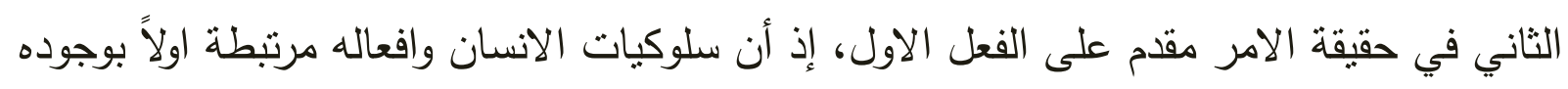

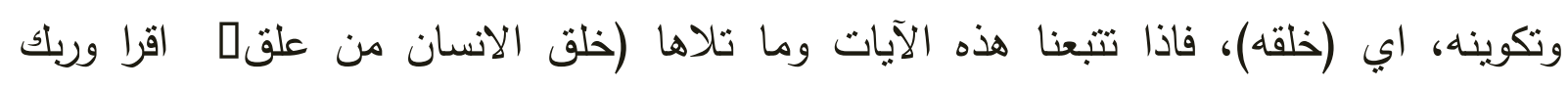

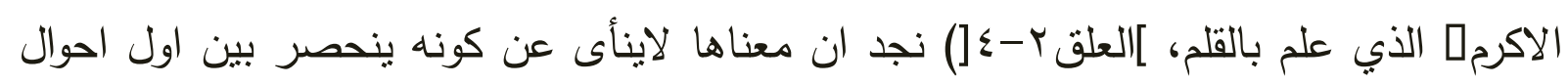

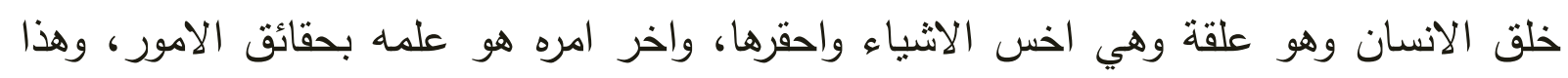




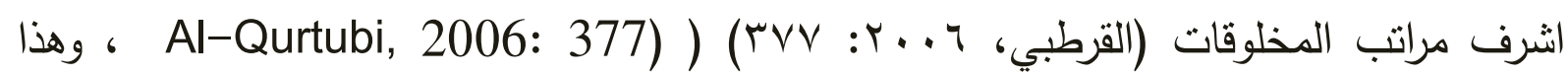
التحول والتطور المرحلي في العلم بالأثياء بتطلب مدبراً ومقدراً ألا وهو اله تعالى عز وعلى وعلا الذي

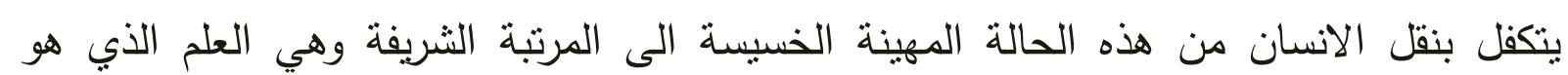
اشرف الصفات الانسانية . الصكان

\section{القرائن اللفظية}

وإذا عدنا الى الآية الكريمة (خلق الانسان من علق ] العلق:ب)، يتجلى تكرار الفعل (خلق) وهذه

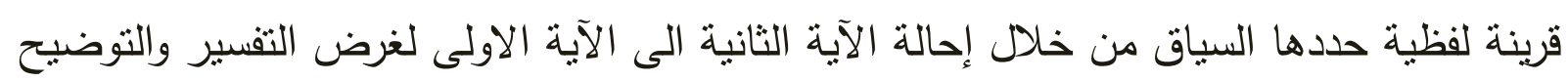

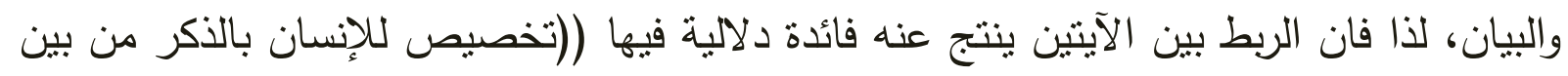

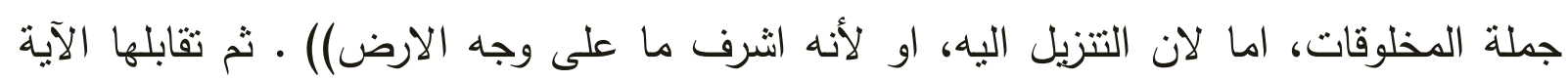

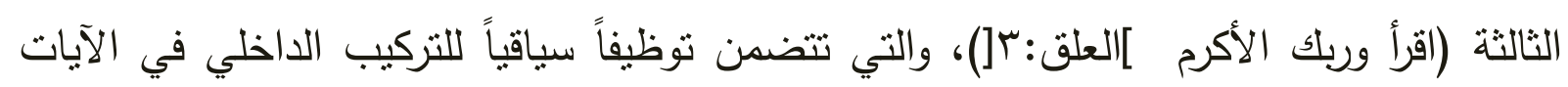

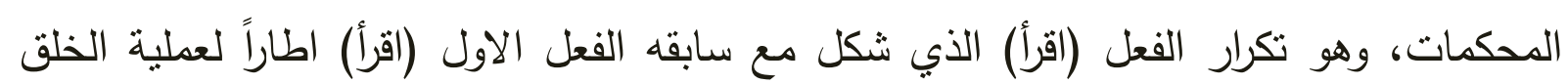

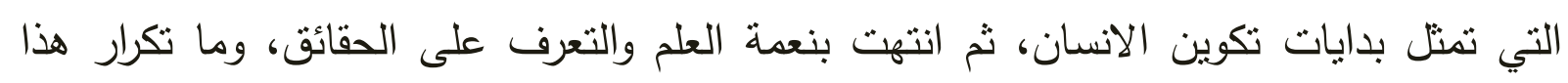
الفعل إلا لغايات ربانية إلهية تتضمن الفهم والادراك المؤدي الى عملية التبليغ تبليغ الرسالة

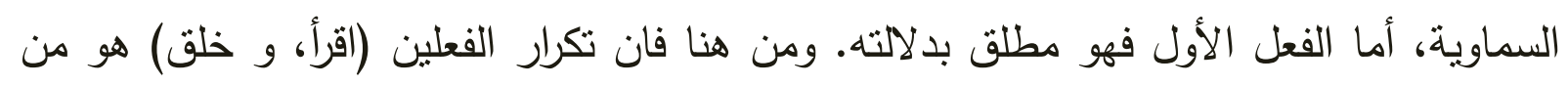

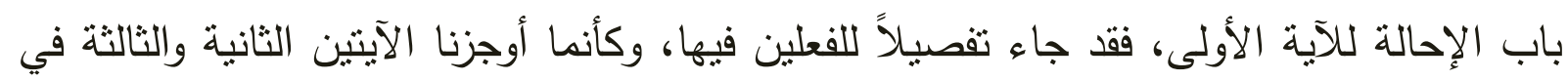
الآية الأولى، وهذا أسلوب بلاغي يستعمل في جل خطاباتتا فكيف بكلام الله عز وجل؟!

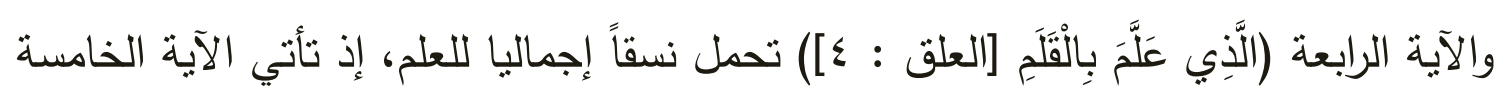

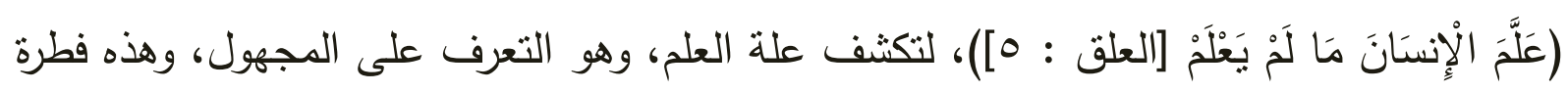

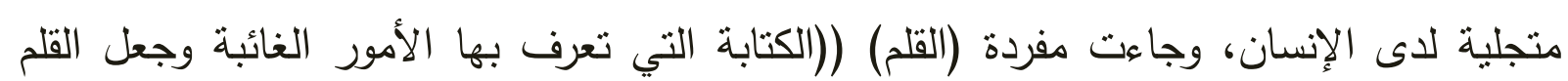

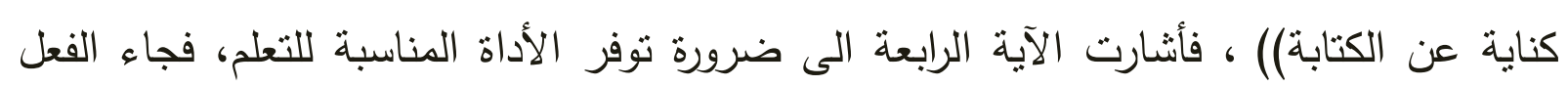
مقترناً بمبنى يحمل (التضام):

التضام:

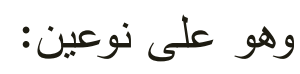
ا ـ تضام الجملة: ويتحقق بعلاقة التراكيب داخل الجملة. 
r. تضام نصي: ويتحقق بترابط نسقي سياقي معنوي يحتمل دلالات نرتبط بالجمل المكونة في النص، كما في الآيات المذكورة انفاً.

نضرب مثالاً على الآية المباركة، لفظة (الإنسان) وهو تضام داخل الجملة، إذ انضمت

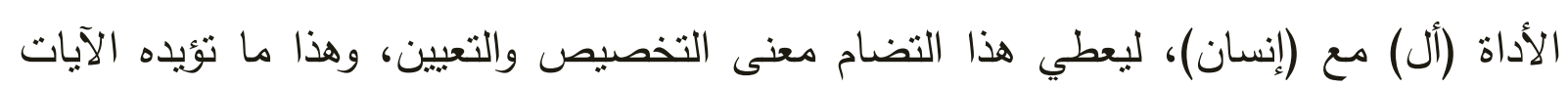

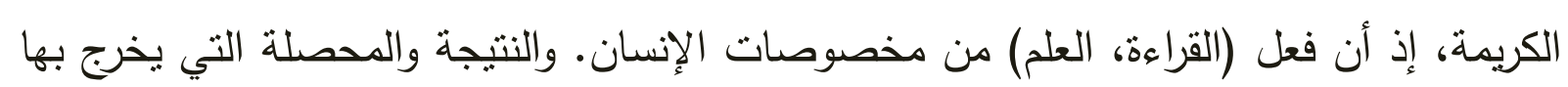

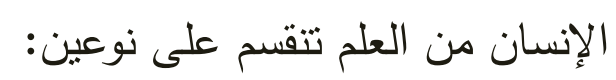
الأول: علم يهدي الى الحق. الثاني: علم يوظف للباطل. ونجد الآية السادسة (كَلَّ إِنَّ الْإِنسَانَ لَيَطْنَى [العلق : ج])، قد أنشارت الى المعنى الثناني

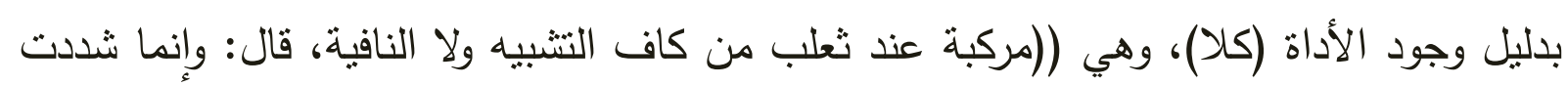
لامها لتقوية المعنى، ولدفع توهم بقاء معنى الكلمتين... وهي عند سيبويه والخليل والمبرد والزجاج

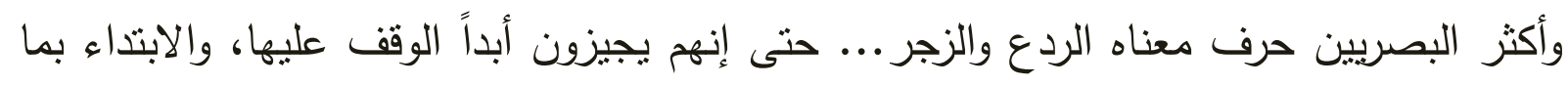

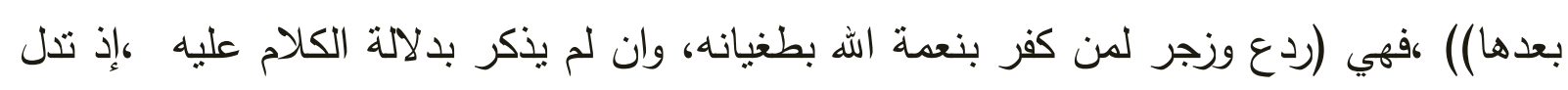

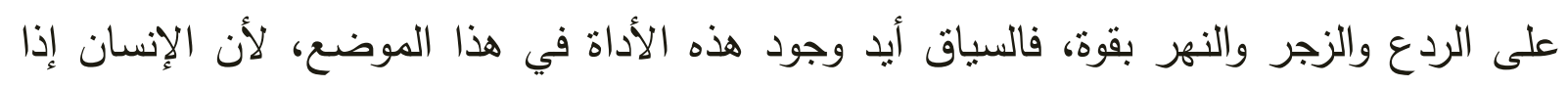
وظّف علمه للباطل سيطغى، والطغيان يؤدي بالإنسان الى الاستغناء عن الله (والعياذ باله)، وجاءت الآية ذاتها حاملة توكيداً وتخصيصاً لتتلاءم مع مفردة (كلاندان. وتجيء الآية الثامنة (أن إِلَى رَبِّكَ الرُّجَْىى [العلق: ^])، لتوضح معنى الردع والنهر موظفة

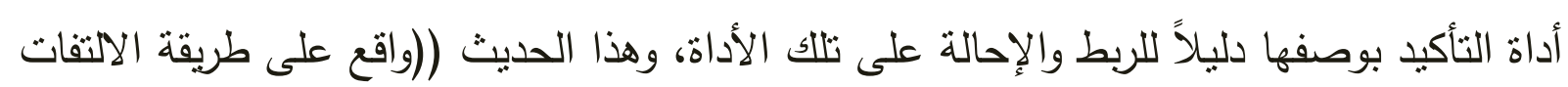

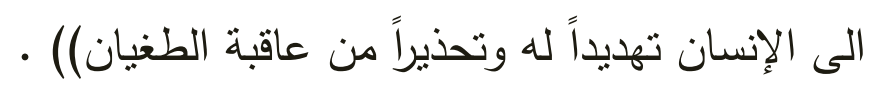
_ - الاستفهامات:

أما الاستقهامات التي وردت في السورة المباركة، فإذا نظرنا الى الآية التاسعة (أَرَكَيْنَتَ الثَّني

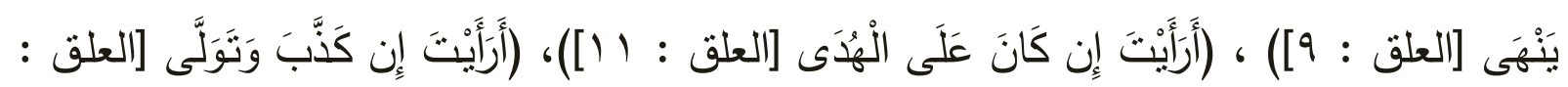

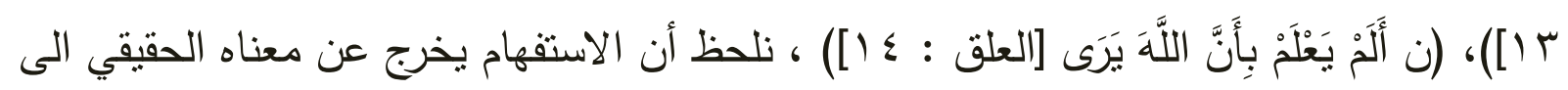

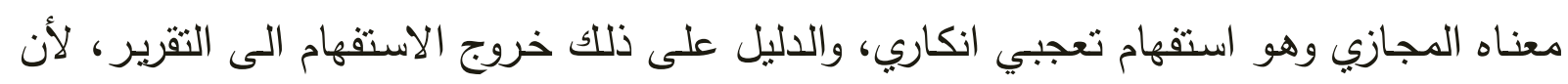

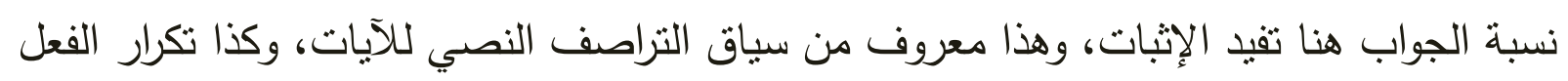


معه (أرايت)فالفعل (رأى) يدل على الروئة البصرية التي تعتمد على أمر حاصل في الحقيقة، وما

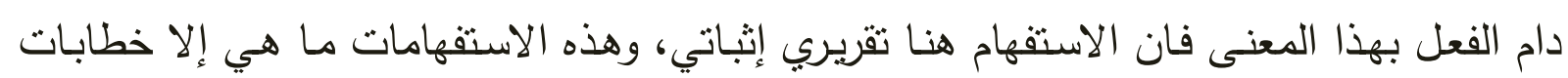

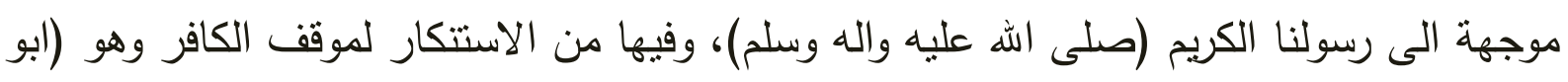

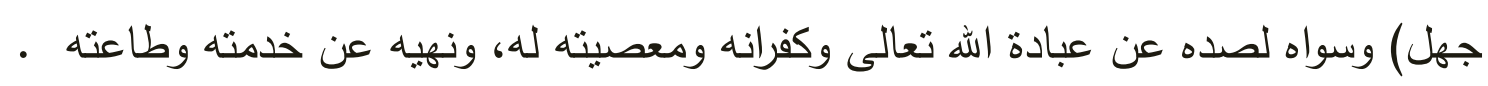

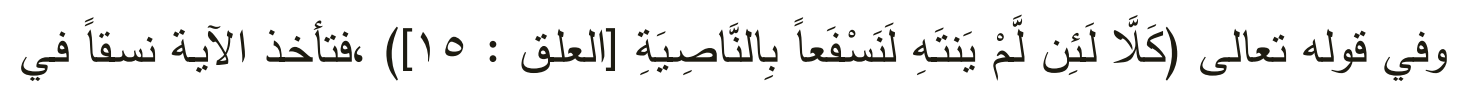
النهر والزجر الثنديدين من خلال ايراد صيغة الجواب (كلّا)، والذي يتباين في معناه عمّا وضحناه

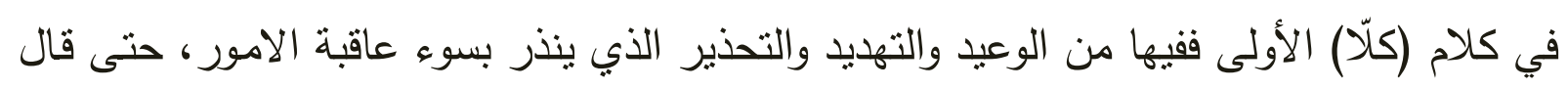

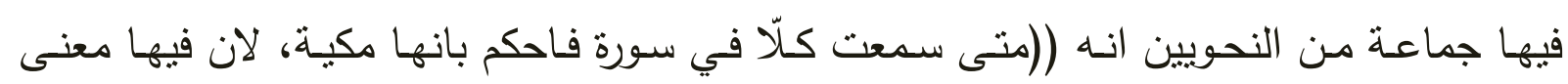

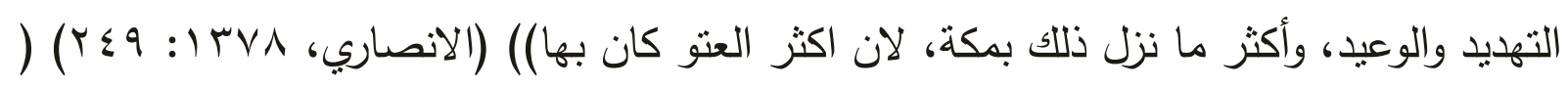

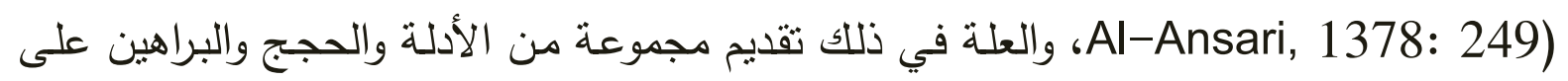
تمادي الانسان في طغيانه بأساليب شتى ذكرت في الآيات الآنفة الذكر لذا جاءت فئ (كلّا) مؤكدة

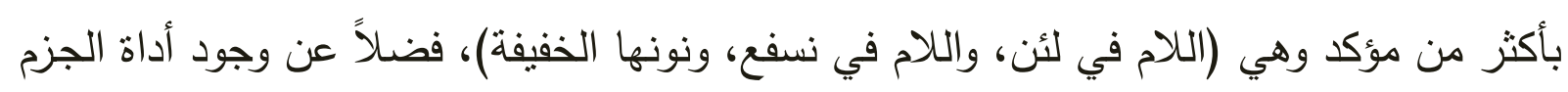

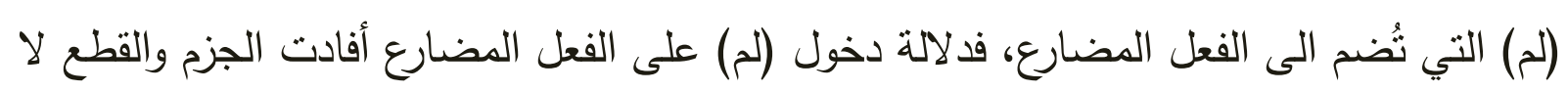

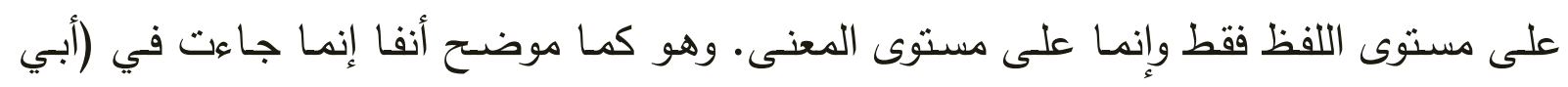

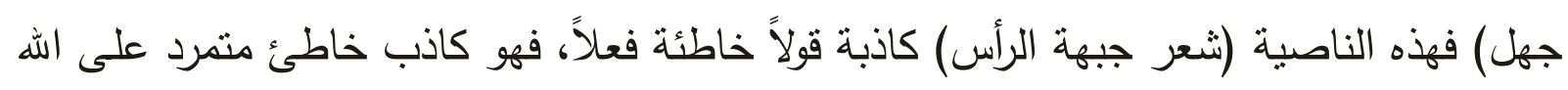

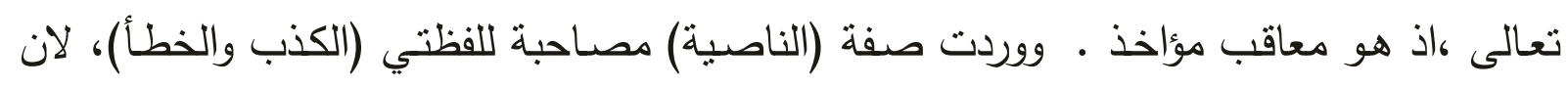

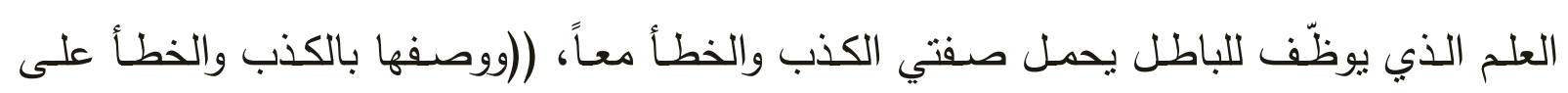
الاسناد المجازي وهما في الحقيقة لصاحبها، وفيه من الحسن والجزالة ما ليس في قولك ناصية البادية كاذب خاطئ)()، ثم ننتقل الـى الآيـة السابعة عشرة (فَلَيَدْعُ نَادِيَهه [العلق : IV])، نلاحظ ان النتيجة في رجوع

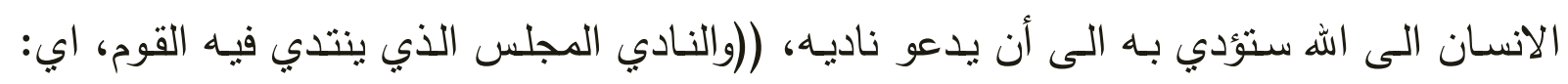

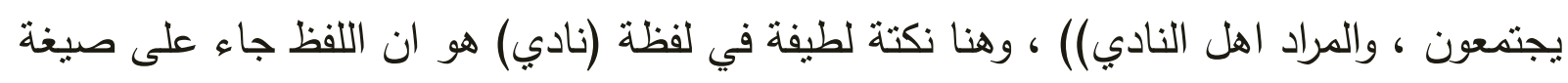

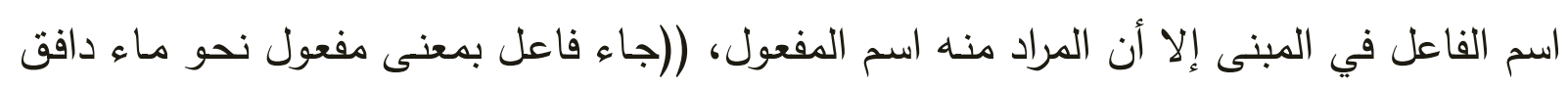

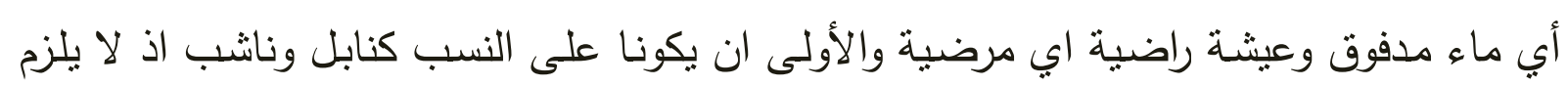

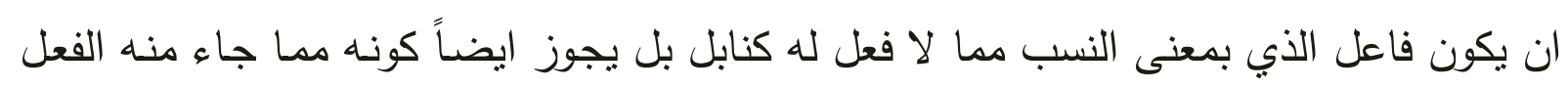

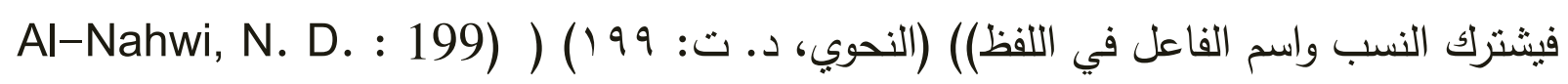


، وفي هذا الاستعمال معنى بلاغي مجازي يحمل انزياحاً قل نظيره في دلالة اللفظة إذ لو جاءت هذات

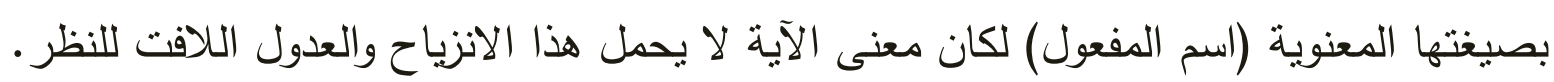

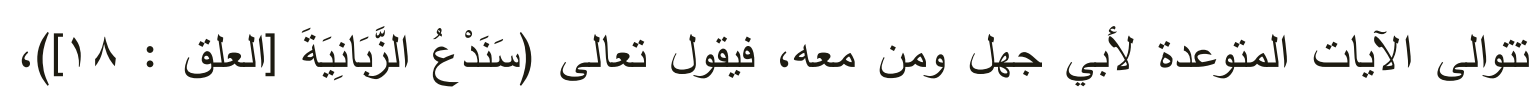

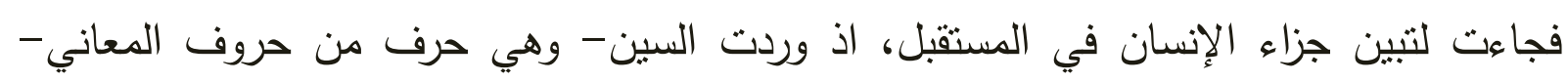

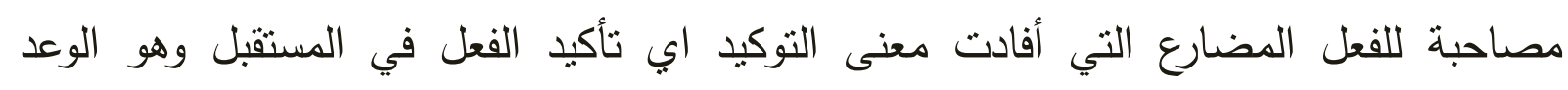

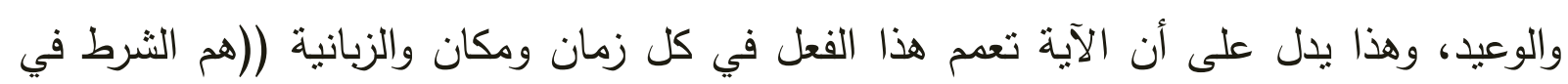

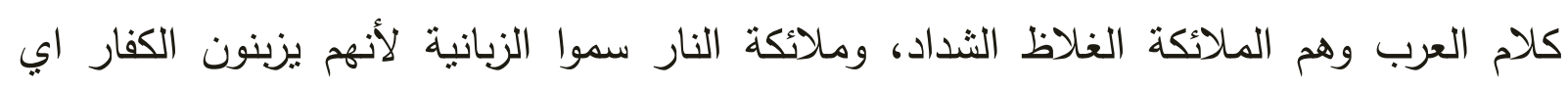

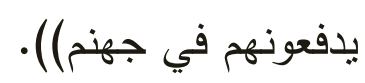

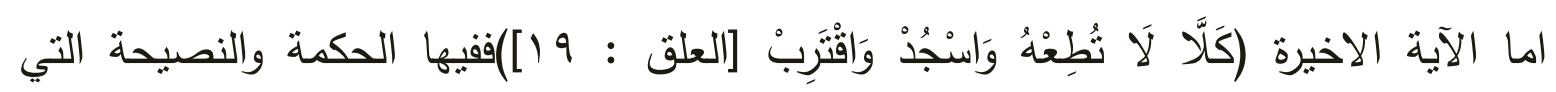
يتوخاها الباري عز وجل ضد الفعل المشين المهين، والدليل على ذللك ورود أداتين للنهي هما:

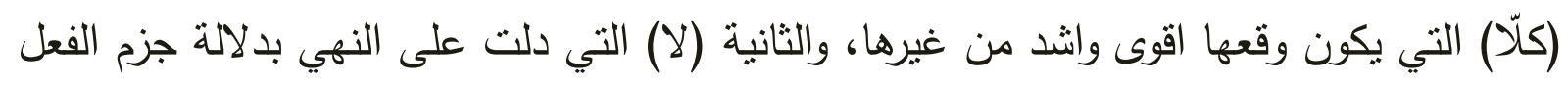

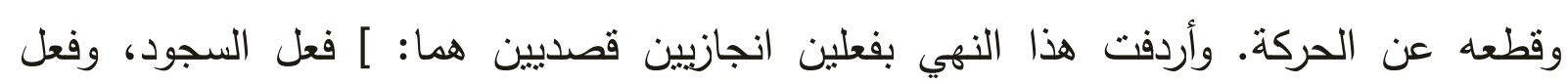

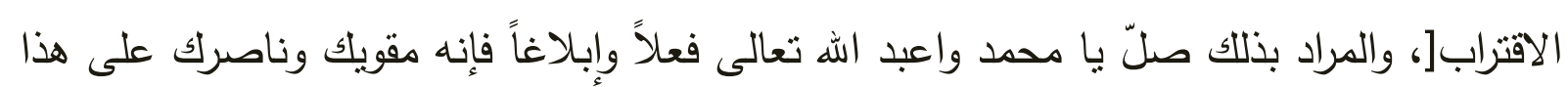

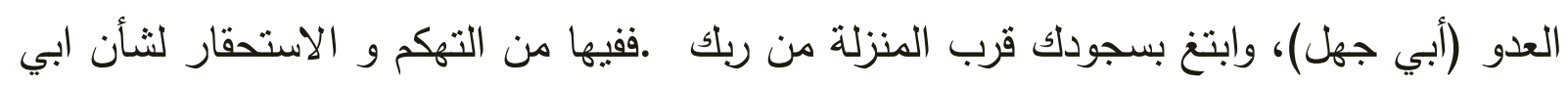

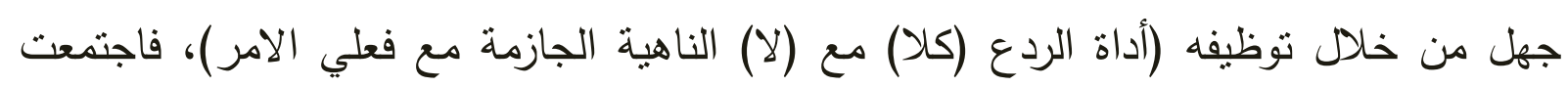

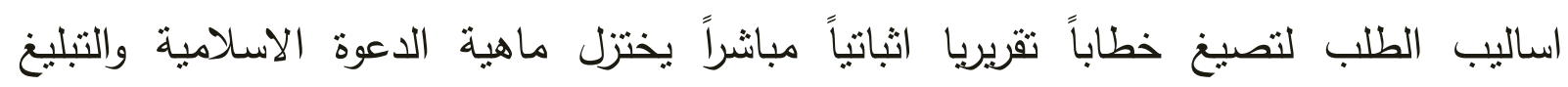
المحمدي. 
المصادر :

القرآن الكريم

- شرح ابن عقبل، بهاء الدين عبداله بن عقيل، (ت

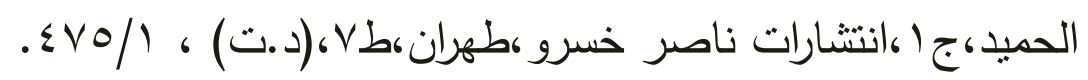

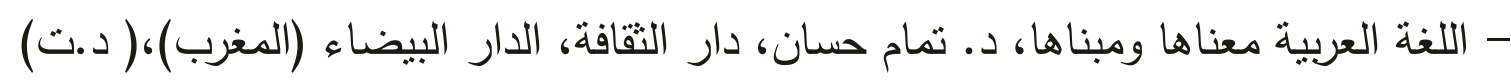
$1 \vee 9$ 。

$$
\begin{aligned}
& \text { - ينظر : (المرجع نفسه) ، IV9 }
\end{aligned}
$$

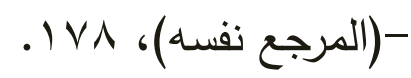

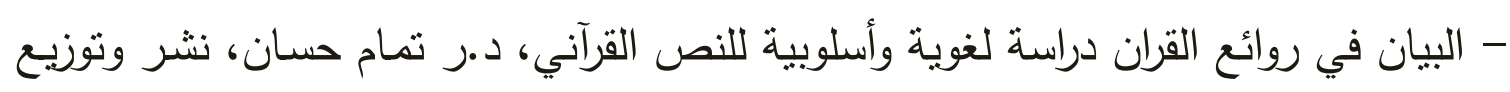

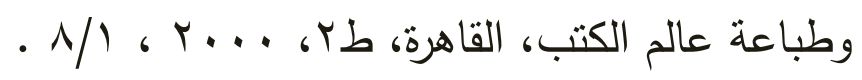

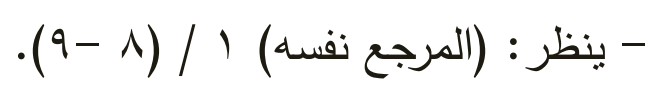

- اللغــة : جوزيـــ فندريس تـر : عبدالحميد الدواخلي ، ومحمد القصـاص، مكتبـة الأنجلو

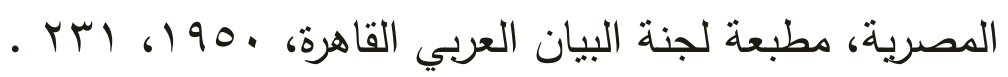

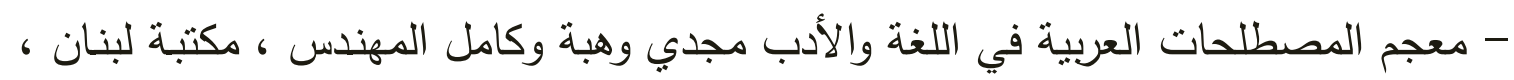

$$
\text { . YrA ، 19V9 }
$$

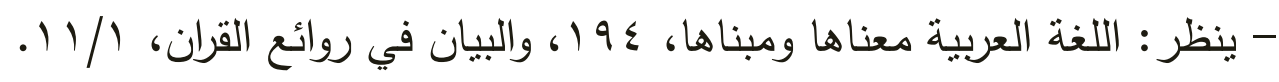

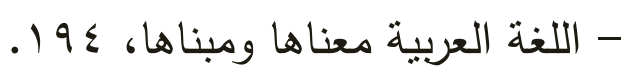

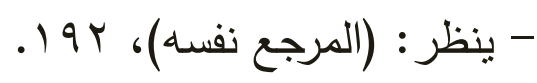

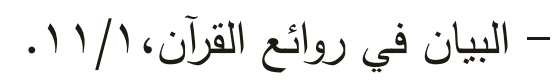

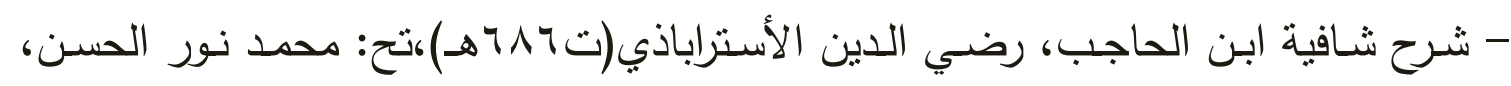

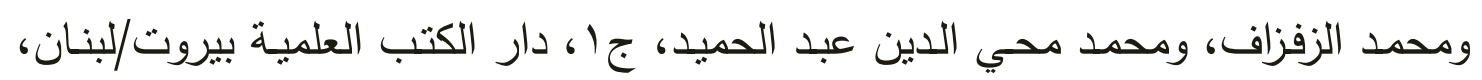

$$
.7 \text {. } 19 \vee 0
$$

- ينظر : الخلاصة النحوية، د. تمام حسان، نشر وتوزيع وطباعة عالم الكتب، القاهرة، طب،

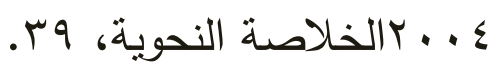

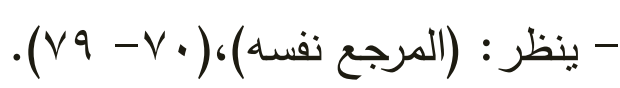

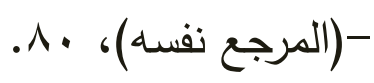




$$
\begin{aligned}
& \text { - ينظر : (المرجع نفسه)، . - }
\end{aligned}
$$

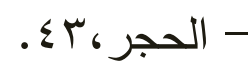

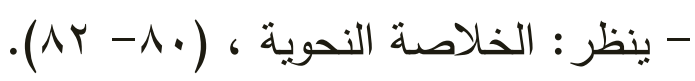

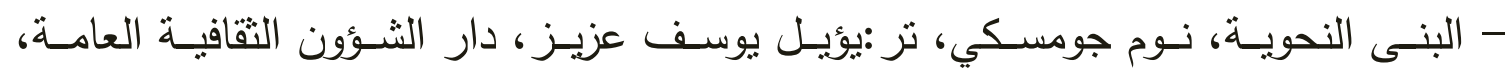
الط، 19N19، 19

- الفيل ، 1.

- الفاتحة، .

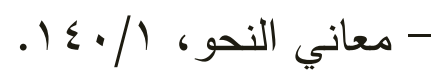

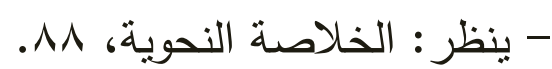

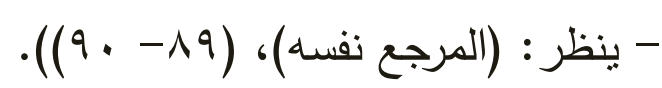

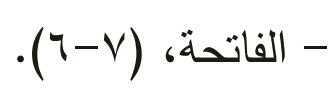

- ينظر : الخلاصة النحوية، ( • (- (1) - (1).

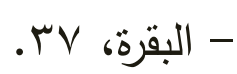

- التصريف الملوكي، ابو الفتح عثمان بن جني (ت بو بهـ) ،تح: د. البدراوي زهران ، طبع

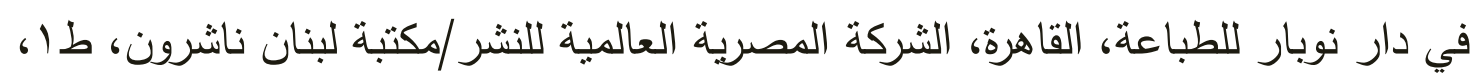

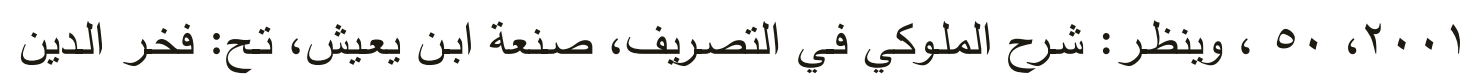

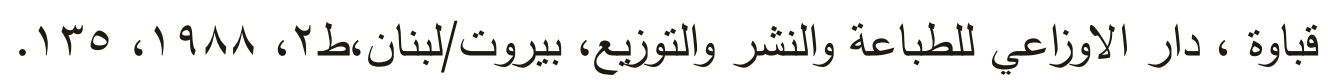

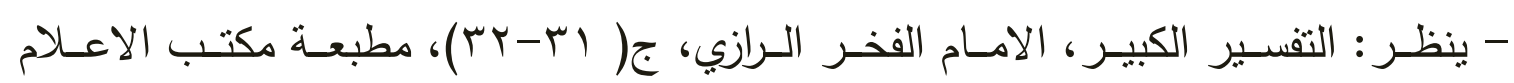

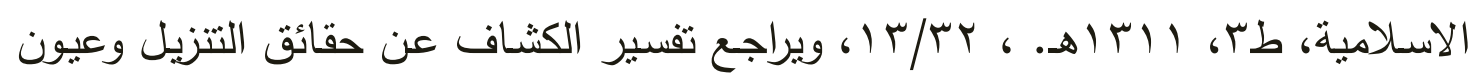

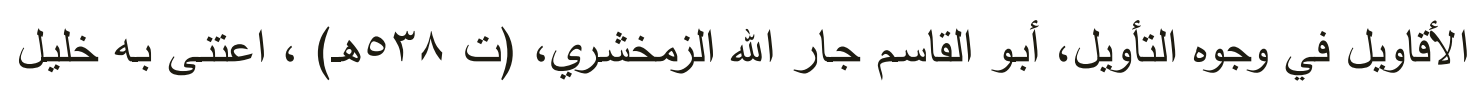

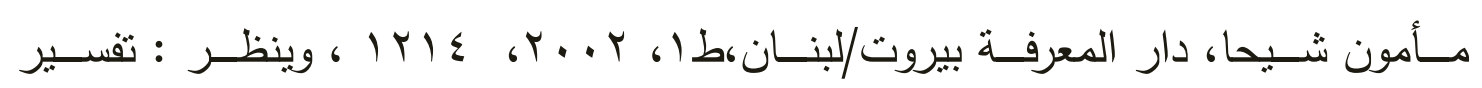

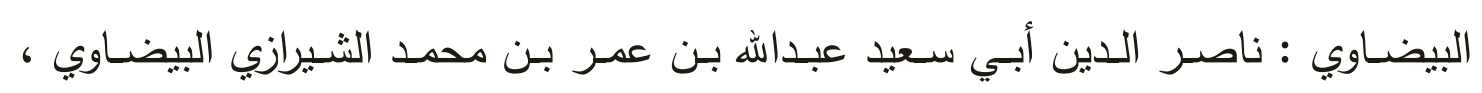

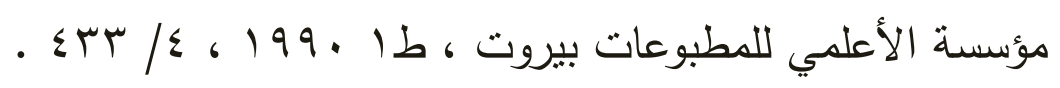

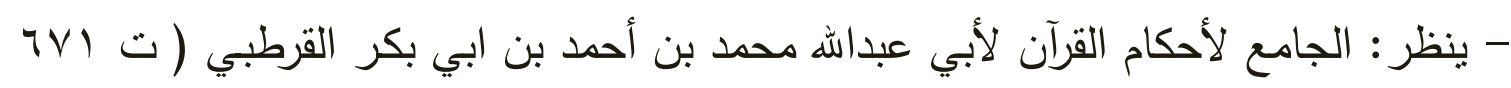

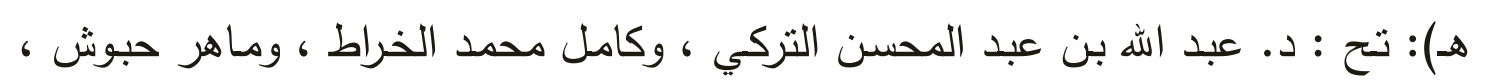

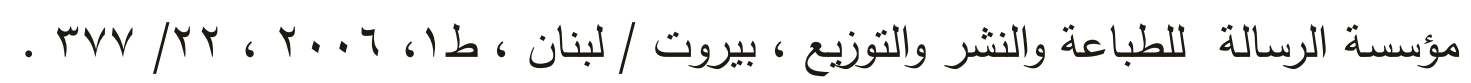

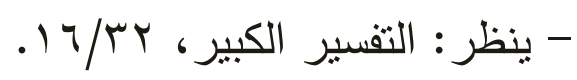




$$
\begin{aligned}
& \text { - ينظر : (المصدر نفسه)، ب/ 10/. }
\end{aligned}
$$

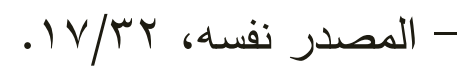

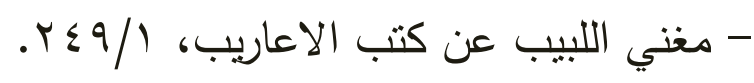

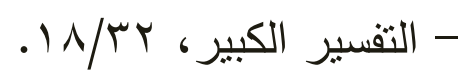

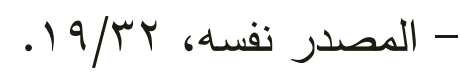

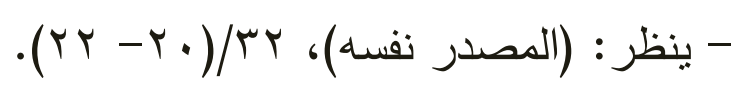

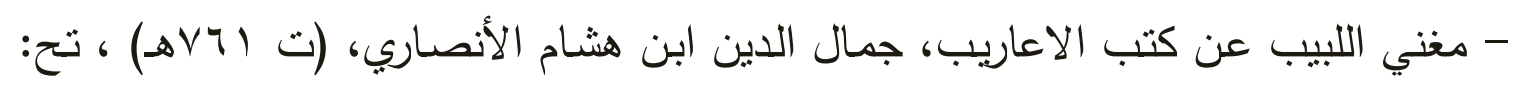

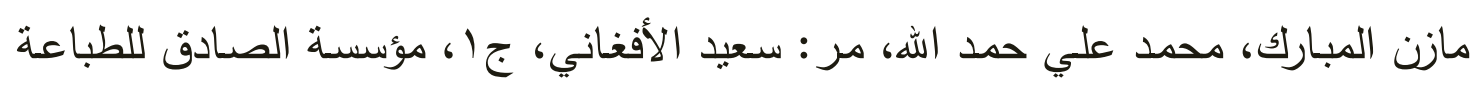

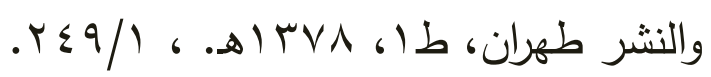

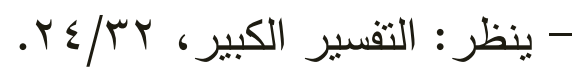

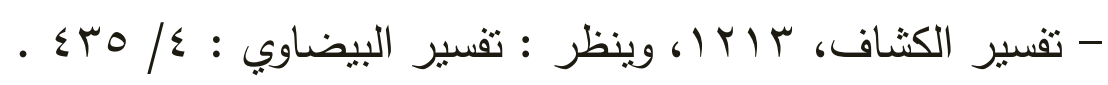

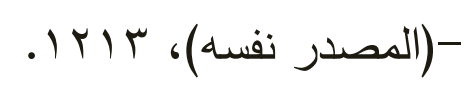

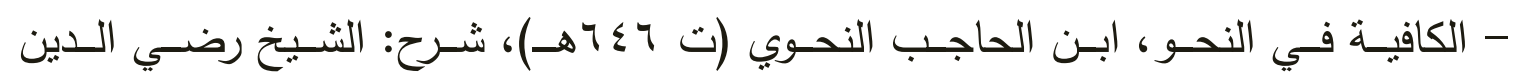

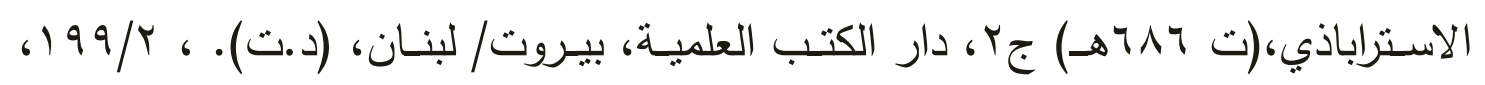

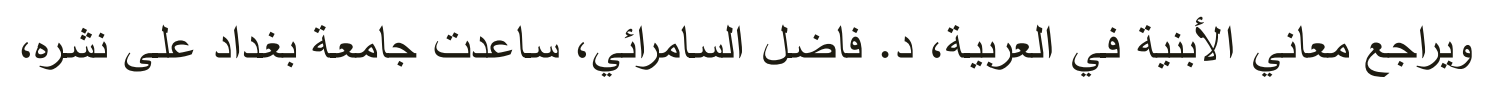

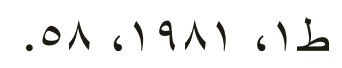

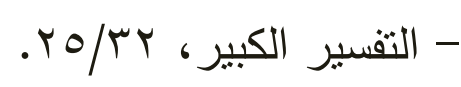

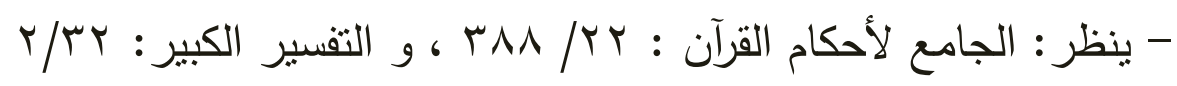

